\title{
Current Smoking With or Without Chronic Bronchitis is Independently Associated With Goblet Cell Hyperplasia in Healthy Smokers and COPD Subjects: an Analysis of the SPIROMICS Cohort
}

Victor Kim ( $\nabla$ victor.kim@tuhs.temple.edu )

Temple University School of Medicine https://orcid.org/0000-0002-1385-1571

Stephanie Jeong

Temple University Health System Inc

Huaqing Zhao

Temple University Health System Inc

Jennifer Kraft

Temple University Health System Inc

Mehmet Kesimer

University of North Carolina at Chapel Hill

Richard Boucher

University of North Carolina at Chapel Hill

James Michael Wells

University of Alabama at Birmingham

Stephanie Christenson

University of California San Francisco

Meilan K Han

University of Michigan Medical School

Mark Dransfield

University of Alabama at Birmingham

Robert Paine

University of Utah Hospital

Christopher B Cooper

University of California Los Angeles Health System

Igor Barjaktarevic

University of California Los Angeles Health System

Russell P Bowler

National Jewish Health

Jeffrey $L$ Curtis

University of Michigan 


\section{Robert J Kaner}

NewYork-Presbyterian Hospital/Weill Cornell Medical Center

\section{Sara L O'Beirne}

NewYork-Presbyterian Hospital/Weill Cornell Medical Center

\section{Wanda K O'Neal}

University of North Carolina at Chapel Hill

\section{Stephen I Rennard}

University of Nebraska Medical Center

\section{Fernando J Martinez}

NewYork-Presbyterian Hospital/Weill Cornell Medical Center

\section{Prescott G Woodruff}

University of California San Francisco

\section{Research}

Keywords: Chronic Obstructive Pulmonary Disease, Smoking, Goblet Cell Hyperplasia, Mucin, Chronic Bronchitis

Posted Date: June 15th, 2020

DOI: https://doi.org/10.21203/rs.3.rs-35241/v1

License: (c) (i) This work is licensed under a Creative Commons Attribution 4.0 International License. Read Full License 


\section{Abstract}

Background: COPD, chronic bronchitis (CB) and active smoking have all been associated with large airway goblet cell hyperplasia $(\mathrm{GCH})$ in small studies. Active smoking is strongly associated with $\mathrm{CB}$, but there is a disconnect between $\mathrm{CB}$ clinical symptoms and pathology. Chronic cough and sputum production poorly correlate with the presence of GCH or COPD. We hypothesized that the primary determinant of $\mathrm{GCH}$ in ever smokers with or without airflow obstruction is active smoking.

Methods: Goblet Cell Density (GCD) was measured in 71 current or former smokers [32 subjects without COPD and 39 COPD subjects] in which endobronchial mucosal biopsies were obtained during the SPIROMICS bronchoscopy substudy. Biopsies were stained with Periodic Acid Schiff-Alcian Blue, and GCD was measured as number of goblet cells $/ \mathrm{mm}$ basement membrane by two independent observers in a blinded fashion. GCD was divided into tertiles (1=low, $2=$ medium, $3=$ high) based on $\log _{10}$ transformed values. Multivariable logistic and linear regressions were performed with $\mathrm{CB}$ and current smoking as the independent variables of interest and demographics and $\mathrm{FEV}_{1} \%$ predicted smoking as covariates.

Results: $\log _{10}$ GCD was greater in current smokers compared to former smokers $(1.16 \pm 0.28$ [n=31] vs. $0.85 \pm 0.42$ [ $n=40$ ], $p=0.001$ ). Those with classically defined CB had a greater $\log _{10} G C D$ compared to those without $C B(1.21 \pm 0.31$ [ $n=13]$ vs. $0.94 \pm 0.39$ [ $n=58], p=0.024)$. Similarly, those with $C B$ by the SGRQ definition had a greater $\log _{10}$ GCD compared to those without CB $(1.13 \pm 0.39$ [ $n=25]$ vs. $0.91 \pm 0.39$ [ $n=43$ ], $p=0.028)$. Tertiles 2 and 3 had a greater percent of current smokers compared to tertile $1(16.7,50.0$ and $63.6 \%$ in tertiles 1,2 and 3 , respectively, $p=0.004$ ). Current smoking was independently associated with tertile 3 (high GCD) (OR 4.15, 95\% Cl 1.17, 14.71) whereas CB was not in multivariable logistic regression. Similar results were found with multivariable linear regression for $\log _{10}$ GCD.

Conclusions: GCD is higher in current smokers with and without airflow obstruction and in CB. However, current smoking, but not $\mathrm{CB}$, is independently associated with GCD. These results suggest that $\mathrm{GCH}$ is induced by active smoke exposure and does not necessarily correlate with the clinical symptoms of CB.

\section{Background}

Chronic Obstructive Pulmonary Disease (COPD) is a major cause of morbidity and is the fourth leading cause of death in the United States [1]. Chronic bronchitis (CB) is a common phenomenon in smokers with and without COPD and is characterized by chronic cough and phlegm. CB increases risk of respiratory exacerbations, is associated with higher mortality, and hastens lung function decline [2]. The most well-established risk factor for developing CB is active smoking $[3,4]$.

The pathologic correlate of $\mathrm{CB}$ is thought to be goblet cell hyperplasia (GCH). Small airway mucus plugging is more commonly seen in COPD and increases as the degree of airflow obstruction worsens [5]. $\mathrm{GCH}$ has been shown to involve the peripheral airways in surgical lung specimens from those with $\mathrm{CB}$ [6] and in large airway endobronchial mucosal biopsies in smokers with airflow obstruction $[7,8]$. We have 
previously shown that $\mathrm{GCH}$ was greater in the large airways in those with $\mathrm{CB}$ compared to those without $\mathrm{CB}$ [8]. Additionally, mucus burden has prognostic significance; one study in lung volume reduction surgery patients found that small airway mucous metaplasia inversely correlated with changes in lung function after surgery [9], whereas another study found that the degree of small airway mucus luminal occlusion correlated with mortality [10].

However, there is a disconnect between respiratory symptoms and the magnitude of $\mathrm{GCH}$. Although active smoking is the primary risk factor for $\mathrm{CB}$, not all smokers develop $\mathrm{CB}$, and $\mathrm{CB}$ can affect former smokers as well [3]. One study in advanced emphysema patients found no relationship between cough and sputum symptoms and degree of small airway mucus impaction [11], while an established pathologic measure of mucous gland hyperplasia has little to no correlation with clinical symptoms [12]. We sought to analyze $\mathrm{GCH}$ as it related to smoking status and chronic bronchitis in smokers with and without airflow obstruction. Given the disconnect between the clinical syndrome of CB and airway pathology, we hypothesized that GCH would be more commonly seen in current smokers compared to exsmokers and would not necessarily associate with CB.

\section{Materials And Methods}

The Subpopulations Intermediate Outcome Measures in COPD Study (SPIROMICS) is a prospective cohort study that has enrolled 2,981 subjects across four strata ([1] Never smokers (NS), [2] Current or former smokers without COPD (HS), [3] Mild/Moderate COPD, and [4] Severe COPD). Goblet Cell Density (GCD) was measured in 71 subjects in strata 2-4 (current or former smokers with and without COPD) in which endobronchial mucosal biopsies were obtained during the SPIROMICS bronchoscopy substudy [13]. Methods of measuring GCD were performed as previously described [8]. Briefly, biopsies were stained with Periodic Acid Schiff-Alcian Blue. Goblet cells from 4-6 endobronchial specimens were counted and related to the length of basement membrane using Image $\mathrm{J}$ [14]. If there were fewer than 4 acceptable samples, the subject was excluded ( $n=28$ out of 99 total subjects). GCD was expressed as the number of goblet cells per millimeter of basement membrane. Two observers performed the measurements in a double-blinded fashion. GCD was then $\log _{10}$ transformed to make the distribution of values assume a more Gaussian distribution and were divided into tertiles ( $1=$ low, 2 = medium, $3=$ high GCD).

Airway total mucin concentration was measured in induced sputum samples in a subset of subjects $(n=$ 7 in tertile $1, n=15$ in tertile $2, n=6$ in tertile 3 ) using previously described methods [15]. Sputum was induced by inhalation of hypertonic saline by subjects who had a forced expiratory volume in 1 second of more than $35 \%$ of the predicted value, according to protocol [16] and American Thoracic Society and European Respiratory Society standards [17].

\section{Statistics}


Statistics were performed using SPSS v25 (IBM Corp., Armonk, NY). Intraclass correlation coefficients between the two observers for goblet cells and GCD were calculated. Differences between groups were assessed using either unpaired $t$ tests or one way ANOVA for continuous variables and chi squared tests for categorical variables. Multivariable logistic regression was performed with Tertile 3 (High GCD) as the dependent variable of interest with current smoking, CB classic definition and CB SGRQ definition in separate models with demographics and $\mathrm{FEV}_{1} \%$ predicted as covariates. Additionally, multivariable linear regression was performed with the same covariates for $\log _{10}$ GCD. A p value of less than 0.05 was considered statistically significant.

\section{Results}

Intraclass correlation coefficients between the two observers for goblet cells and GCD were 0.932 and 0.968 , respectively ( $<<0.0001$ for both). See Fig. $1 \mathrm{a}$ for a histogram of the distribution of GCD. Figure $1 \mathrm{~b}$ shows the distribution of $\log _{10}$ GCD. The median value for GCD was $11.034 \mathrm{GC} / \mathrm{mm}$. $\log _{10}$ GCD was greater in those that were currently smoking compared to former smokers $(1.16 \pm 0.28[n=31]$ vs. $0.85 \pm$ $0.42[n=40], p=0.001$ ). Those with $C B$ defined using the classic definition (cough and phlegm for $>$ 3 months/year for at least 2 consecutive years) had a greater $\log _{10}$ GCD compared to those without CB $(1.21 \pm 0.31$ [ $n=13]$ vs. $0.94 \pm 0.39$ [ $n=58], p=0.024)$. Similarly, those with CB by the SGRQ definition (cough and phlegm almost every day or several days a week for the past 4 weeks) had a greater $\log _{10}$ GCD compared to those without CB $(1.13 \pm 0.39$ [n=25] vs. $0.91 \pm 0.39$ [n=43], p = 0.028). See Fig. 2 .

The characteristics of the three tertiles are shown in Table 1. 5.0\% of ex-smokers and 33.3\% of current smokers had classically defined CB. Tertiles 2 and 3 tended to be younger than tertile $1(64.9 \pm 7.5,59.8 \pm$ $9.3,59.8 \pm 8.2$ years in tertiles 1,2 and 3 , respectively, $p=0.06$ ). The groups were similar in gender, race distribution and body mass index. $16.7 \%$ of those in tertile 1 were current smokers, whereas in tertiles 2 and 3 the percentages of those that were current smokers were $50.0 \%$ and $63.6 \%$, respectively $(p=0.004)$. The percentages of subjects in each tertile with Classic CB or SGRQ CB were not significantly different. Lung function tended to be lower in tertiles 2 and 3 compared to tertile $1\left(\mathrm{FEV}_{1} 95.9 \pm 20.8,84.1 \pm 16.4\right.$, $85.4 \pm 19.6 \%$ predicted for tertiles 1,2 and 3 , respectively, $p=0.069)$. 6 -minute walk distance, SGRQ scores, $\mathrm{mMRC}$ dyspnea scores and exacerbation histories were similar between tertiles. CAT scores tended to be worse in tertiles 2 and 3 compared to tertile $1(7.45 \pm 7.58,12.52 \pm 8.46,11.83 \pm 7.95$ for tertiles 1,2 , and 3 , respectively, $p=0.08$ ). Mucin concentrations were greater in tertiles 2 and 3 but the differences were not statistically significant $(1185 \pm 967,2211 \pm 1482,2312 \pm 1915 \mu \mathrm{g} / \mathrm{mL}$ in tertiles 1,2 and 3 , respectively, $p=0.279)$. When GCD was divided into two groups by the median value into Low GCD and High GCD, mucin concentrations were higher in the High GCD group. See Fig. 3. 
Table 1

Baseline Characteristics.

\begin{tabular}{|c|c|c|c|c|c|c|}
\hline \multirow[b]{2}{*}{ Age (years) } & \multicolumn{2}{|c|}{ Tertile $1(n=24)$} & \multicolumn{2}{|c|}{ Tertile $2(n=24)$} & \multicolumn{2}{|c|}{ Tertile $3(n=23)$} \\
\hline & 64.9 & \pm 7.5 & 59.8 & \pm 9.3 & 59.8 & \pm 8.2 \\
\hline Gender (\%Male) & \multicolumn{2}{|c|}{$13(54.2)$} & \multicolumn{2}{|c|}{$13(54.2)$} & \multicolumn{2}{|c|}{$16(69.6)$} \\
\hline Race (\% Caucasian) & \multicolumn{2}{|c|}{20 (83.3) } & \multicolumn{2}{|c|}{$16(66.7)$} & \multicolumn{2}{|c|}{$16(69.6)$} \\
\hline BMI (kg/m2) & 29.1 & \pm 4.6 & 28.4 & \pm 4.5 & 26.9 & \pm 5.7 \\
\hline Current Smoker [n (\%)]* & \multicolumn{2}{|l|}{$4(16.7)$} & \multicolumn{2}{|c|}{$12(50.0)$} & \multicolumn{2}{|c|}{$14(63.6)$} \\
\hline Pack Year History & 45.2 & \pm 19.8 & 48.3 & \pm 25.7 & 43.5 & \pm 20.6 \\
\hline CB Classic Def [n (\%)] & \multicolumn{2}{|l|}{$2(8.3)$} & \multicolumn{2}{|l|}{$4(16.7)$} & \multicolumn{2}{|c|}{$7(30.4)$} \\
\hline CB SGRQ Def [n (\%)] & \multicolumn{2}{|l|}{$5(22.7)$} & \multicolumn{2}{|l|}{$8(34.8)$} & \multicolumn{2}{|c|}{$12(52.2)$} \\
\hline FEV1\%Pred & 95.9 & \pm 20.8 & 84.1 & \pm 16.4 & 85.4 & \pm 19.6 \\
\hline FEV1/FVC (\%pred) & 92.2 & \pm 15.5 & 83.8 & \pm 14.7 & 84.0 & \pm 16.7 \\
\hline No COPD [n(\%)] & \multicolumn{2}{|c|}{$15(62.5)$} & \multicolumn{2}{|l|}{$7(29.2)$} & \multicolumn{2}{|c|}{$10(43.5)$} \\
\hline COPD [n(\%)] & \multicolumn{2}{|l|}{$9(37.5)$} & \multicolumn{2}{|c|}{$17(70.8)$} & \multicolumn{2}{|c|}{$13(56.5)$} \\
\hline 6MWD (m) & 477 & \pm 92 & 439 & \pm 88 & 466 & \pm 66 \\
\hline SGRQ Score & 16.1 & \pm 17.3 & 26.1 & \pm 17.6 & 23.7 & \pm 19.1 \\
\hline mMRC Dyspnea Score & 0.30 & \pm 0.64 & 0.65 & \pm 0.89 & 0.61 & \pm 0.72 \\
\hline CAT Score & 7.45 & \pm 7.58 & 12.52 & \pm 8.46 & 11.83 & \pm 7.95 \\
\hline Exac hx (exac.pt/yr) & 0.08 & \pm 0.28 & 0.54 & \pm 1.18 & 0.41 & \pm 0.80 \\
\hline Sev Exac Hx (exac.pt/yr) & 0.04 & \pm 0.20 & 0.17 & \pm 0.38 & 0.09 & \pm 0.43 \\
\hline GCD (cells/mm)† & 4.30 & \pm 2.18 & 11.20 & \pm 2.00 & 26.06 & \pm 10.59 \\
\hline Mucin Conc $(\mu \mathrm{g} / \mathrm{mL})$ & 1185 & \pm 967 & 2211 & \pm 1482 & 2312 & \pm 1915 \\
\hline \multicolumn{7}{|c|}{ 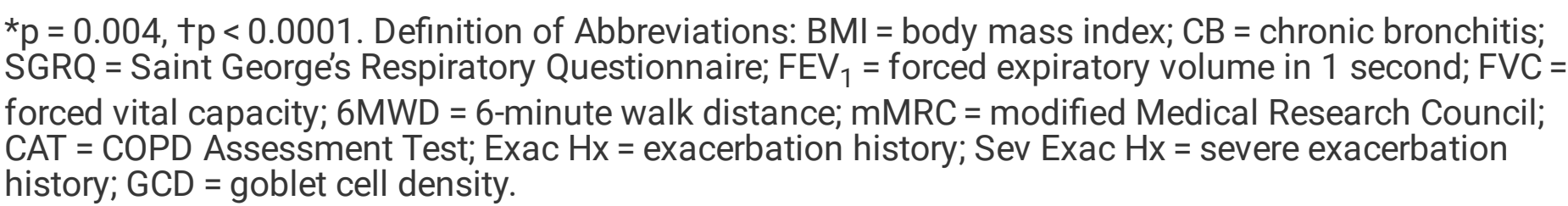 } \\
\hline
\end{tabular}

Multivariable logistic regressions for tertile 3 (high $\log _{10}$ GCD) using current smoking, Classic CB and SGRQ CB in separate models are shown in Table 2. Current smoking was independently associated with High GCD after adjusting for other covariates (OR 4.15, 95\% Cl 1.17, 14.71). Neither Classic CB nor SGRQ CB were associated with High GCD (OR 3.14, 95\% Cl 0.86, 11.51 and OR 2.42, 95\% Cl 0.77, 7.56, 
respectively). Multivariable linear regressions for $\log _{10} G C D$ are shown in Table 3. Model one uses current smoking, Classic CB or SGRQ CB as independent variables of interest with age, gender and race as covariates. Model two adjusts for age, gender, race, and $\mathrm{FEV}_{1}$ \%predicted. Current smoking and Classic CB were independently associated with $\log _{10}$ GCD in model one (estimate 0.265 , SE $0.103, p=0.012$ and estimate 0.257 , SE $0.115, p=0.029$, respectively). However, in model two, only current smoking was independently associated with $\log _{10}$ GCD (estimate 0.226 , SE $0.100, p=0.028$ ).

Table 2

Multivariable logistic regression for Tertile 3 (high GCD). Covariates include age, gender, race, and $\mathrm{FEV}_{1} \%$ predicted.

\begin{tabular}{|llll|}
\hline & OR & $95 \% \mathrm{Cl}$ \\
\hline Current Smoking & 4.15 & 1.17 & 14.71 \\
\hline CB Classic Def & 3.14 & 0.86 & 11.51 \\
\hline CB SGRQ Def & 2.42 & 0.77 & 7.56 \\
\hline
\end{tabular}

Table 3

Multivariable linear regression for Tertile $3 \log _{10}$ GCD (high GCD). Model one is adjusted for age, gender, and race; Model two is adjusted for age, gender, race, and $\mathrm{FEV}_{1} \%$ predicted.

\begin{tabular}{|lllllll|}
\hline & Model 1 & \multicolumn{5}{c|}{ Model 2 } \\
\hline & Estimate & S.E. & $\mathrm{p}$ & Estimate & S.E. & $\mathrm{p}$ \\
\hline Current Smoking & 0.265 & 0.103 & $\mathbf{0 . 0 1 2}$ & 0.226 & 0.100 & $\mathbf{0 . 0 2 8}$ \\
\hline CB Classic Def & 0.257 & 0.115 & $\mathbf{0 . 0 2 9}$ & 0.218 & 0.111 & 0.054 \\
\hline CB SGRQ Def & 0.190 & 0.098 & 0.058 & 0.118 & 0.100 & 0.240 \\
\hline
\end{tabular}

\section{Discussion}

We showed that GCD was greater in those that were currently smoking and in those with CB. Similarly, those with high $\log _{10}$ GCD were more likely to be current smokers but not CB using either definition. Using multivariable logistic regression, we showed that current smoking, but not $\mathrm{CB}$, was independently associated with high $\log _{10}$ GCD. Similar results were seen with multivariable linear regression. These results suggest that $\mathrm{GCH}$ is induced by active smoke exposure and does not necessarily translate into the clinical symptoms of $\mathrm{CB}$.

This is the first study that demonstrates the complex interrelationship between $\mathrm{CB}$, smoking, and GCH in a large cohort of extensively characterized smokers with and without airflow obstruction. A prior study of epithelial mucin stores compared goblet cell measures in 24 active smokers and 19 nonsmoking controls; 
mucin stores were greater in the smokers, especially those with airflow limitation [7]. However, it was not clear whether the smokers had CB. In a prior report, we contrasted the GCD in 15 subjects with moderate to severe COPD, 12 smokers without COPD, and 11 healthy nonsmokers [8]. Interestingly, we found that the smokers without airflow obstruction had the greatest degree of $\mathrm{GCH}$ while those with $\mathrm{CB}$ had a greater $\mathrm{GCD}$ than those without $\mathrm{CB}$ [8]. Another study revealed that $\mathrm{GCH}$, assessed using qualitative measures, was more commonly seen in habitual tobacco smokers compared to nonsmoking controls [18]. Our data expand upon these findings in a much larger cohort with the addition of the relationship of current smoking with $\mathrm{CB}$.

We also showed that mucin concentrations in induced sputum were greater in those with High GCD. This is the first study that has shown a relationship between large airway $\mathrm{GCH}$ and sputum mucins. It has been speculated that mucus is expectorated from large airways to produce sputum, suggesting sputum mucin concentration and large airway GCH should be related, but few studies have addressed the correspondence between these two metrics of mucus production. This association may have clinical relevance as well, as sputum mucins have been related to $C B$, respiratory exacerbations and peripheral airway disease in 917 subjects in the SPIROMICS cohort [15, 19]. Unlike this larger study, our analysis did not show a statistically greater degree of sputum mucins in chronic bronchitics. This may be due to the small sample size or that some mucins arise from submucosal glands that we were not able to examine.

The prevalence of $\mathrm{CB}$ ranges anywhere from $12.2 \%$ in smokers without airflow obstruction to $74 \%$ in some COPD cohorts [20-22]. CB has been related to an accelerated rate of lung function decline, worse health related quality of life, increased mortality, and an increased risk of respiratory exacerbations in individuals with and without COPD [20, 23-25]. In the Copenhagen City Heart Study, chronic mucus hypersecretion was associated with an increased rate of $\mathrm{FEV}_{1}$ decline over time [24]. Analyses of the COPDGene study and SPIROMICS showed that CB in those without airflow obstruction was associated with respiratory exacerbations $[20,26]$, and in those with airflow obstruction CB was associated with a two-fold increased rate of exacerbations in longitudinal follow-up [27]. In the Tucson Epidemiologic Survey of Airway Obstructive Disease, younger patients with CB had a greater mortality compared to those without CB [28]. In a study of nearly 48,000 men and women, $C B$ was associated with an increased duration of hospitalization and a greater all-cause mortality [25].

The most well described risk factor for $\mathrm{CB}$ is active smoking. A large study of more than 1,700 Finnish men showed that over 30 years the cumulative incidence of CB in continued smokers was $42 \%$ [29]. A meta-analysis revealed that the relative risk of CB from current smoking was 3.41 [30]. There is also evidence that smoking cessation decreases CB. Over five years, an analysis of the COPDGene study showed that ex-smokers who resumed smoking were more likely to develop $\mathrm{CB}$ and that current smokers who quit were more likely to have their CB resolve [31]. A larger study of over 4,000 subjects followed from ages 20 to 64 showed that those who smoked were more likely to develop chronic mucus hypersecretion and quitting smoking resulted in decreased chronic mucus hypersecretion [4]. 
$\mathrm{GCH}$ is one of the pathologic foundations for $\mathrm{CB}$. The primary mechanisms responsible for excessive mucus in $\mathrm{CB}$ are overproduction and hypersecretion by goblet cells and/or decreased clearance of mucus. Mucus hypersecretion develops as a consequence of cigarette smoke exposure [32,33], acute and chronic viral infection[34] and inflammatory cells may activate mucin gene transcription[35]. The increased epithelial gene expression is associated with metaplastic responses in club cells to assume a goblet cell morphology characterized by overproduction of mucus and hypersecretion associated with increased degranulation. This hypersecretion is compounded by difficulty in clearing secretions because of poor ciliary function, defective mucus hydration, distal airway occlusion, and ineffective cough secondary to respiratory muscle weakness and reduced peak expiratory flow in COPD [5, 35-37].

Unlike the tight correlation between emphysema and lung function, the relationship between airway pathology, physiology and symptom severity is only moderate at best. Large airway GCH correlates poorly with the degree of airflow obstruction [38] or chronic phlegm [39]. Small airway disease has been found in surgical lung specimens from those with advanced emphysema, with no clinical or radiographic evidence to suggest its presence preoperatively $[5,9,40,41]$. More importantly, the degree of small airway GCH is difficult to detect clinically by cough or sputum burden [11]. Our findings shed light on the subject and improve our current understanding. Although both active smokers and those with CB had increased GCD, only current smoking was independently associated with it in multivariable analysis.

There are several limitations that are worthy of mention. Firstly, although the size of the cohort analyzed is large for a bronchoscopy study, its size in comparison to the entire SPIROMICS cohort is small. Secondly, mucin concentrations on the induced sputum samples were only available for 28 subjects, making the distinction of mucin concentrations between groups suboptimal. There was also a lack of never smokers to serve as a control group. Lastly, there may have been within subject differences in GCD based on the areas sampled which could not be assessed.

Nonetheless, we have shown that goblet cell hyperplasia is related more so to current smoking as opposed to the presence or absence of chronic bronchitis, no matter how it is defined. These findings suggest that goblet cell hyperplasia can exist in the absence of chronic bronchitis, again emphasizing the disconnect between clinical symptoms and airway pathology. However, our findings also suggest that current smoking causes goblet cell hyperplasia before chronic bronchitis develops or independently from chronic bronchitis. These findings need to be validated in other studies and their clinical relevance need to be better defined.

\section{Abbreviations}

ANOVA = analysis of variance

ATS $=$ American Thoracic Society

$\mathrm{BMI}=$ body mass index 
$\mathrm{CB}=$ Chronic Bronchitis

COPD = Chronic Obstructive Pulmonary Disease

CT = computed tomography

$\mathrm{FEV}_{1}=$ forced expiratory volume in 1 second

FVC $=$ forced vital capacity

GCD = Goblet Cell Density

$\mathrm{GCH}=$ Goblet Cell Hyperplasia

GOLD = Global Initiative for Chronic Obstructive Lung Disease

mMRC $=$ modified Medical Research Council

SGRQ = Saint George's Respiratory Questionnaire

SPIROMICS = Subpopulations and Intermediate Outcome Measures in COPD Study

\section{Declarations}

\section{Ethics approval and consent to participate}

Each site had IRB approval and all subjects consented to participate

\section{Consent for publication}

All authors provide their consent to participate. There are no individual subject data that are within this manuscript

\section{Availability of data and materials}

More information about the study and how to access SPIROMICS data is at www.spiromics.org.

\section{Competing interests}

The authors declare no competing interests in the design of the study, collection of the data, data analysis or writing of the manuscript.

In the past three years, VK has received personal fees from Gala Therapeutics, AstraZeneca, and Boehringer Ingelheim outside of the submitted work. 
Dr. Curtis reports a grant from $\mathrm{NIH} / \mathrm{NHLBI}$ during the conduct of this study; grants from $\mathrm{NIH} / \mathrm{NHBLI}$, $\mathrm{NIH} / \mathrm{NIAID}$, the Department of Veterans Affairs, and the Department of Defense outside the submitted work; and personal fees from AstraZeneca outside the submitted work.

SJ, JDK, HZ, SLO, FJM, RP, RK, WCM and WGK report no conflicts of interest.

JMW reports grants from $\mathrm{NIH} / \mathrm{NHLBI}$, during the conduct of the study; grants from $\mathrm{NIH} / \mathrm{NCATS}$, grants from Bayer, grants and other from GSK, other from Boehringer Ingelheim, grants and other from Mereo BioPharma, other from ICON, other from PRA, other from Vertex Pharmaceuticals, outside the submitted work;

SIR was employed by AstraZeneca until November, 2019 and has consulted for GSK and BerGenBio.

PGW reports personal fees from Glaxosmithkline, personal fees from NGM biopharmaceuticals, personal fees from Amgen, personal fees from Glenmark Pharmaceuticals, personal fees from Theravance, personal fees from Clarus Ventures, personal fees from Astra Zeneca, personal fees from 23andMe, personal fees from Sanofi, personal fees from Regeneron, personal fees from Genentech, outside the submitted work.

\section{Funding Support and Acknowledgements}

The authors thank the SPIROMICS participants and participating physicians, investigators and staff for making this research possible. More information about the study and how to access SPIROMICS data is at www.spiromics.org. We would like to acknowledge the following current and former investigators of the SPIROMICS sites and reading centers: Neil E Alexis, MD; Wayne H Anderson, PhD; Mehrdad Arjomandi, MD; Igor Barjaktarevic, MD, PhD; R Graham Barr, MD, DrPH; Lori A Bateman, MSc; Surya P Bhatt, MD; Eugene R Bleecker, MD; Richard C Boucher, MD; Russell P Bowler, MD, PhD; Stephanie A Christenson, MD; Alejandro P Comellas, MD; Christopher B Cooper, MD, PhD; David J Couper, PhD; Gerard J Criner, MD; Ronald G Crystal, MD; Jeffrey L Curtis, MD; Claire M Doerschuk, MD; Mark T Dransfield, MD; Brad Drummond, MD; Christine M Freeman, PhD; Craig Galban, PhD; MeiLan K Han, MD, MS; Nadia N Hansel, MD, MPH; Annette T Hastie, PhD; Eric A Hoffman, PhD; Yvonne Huang, MD; Robert J Kaner, MD; Richard E Kanner, MD; Eric C Kleerup, MD; Jerry A Krishnan, MD, PhD; Lisa M LaVange, PhD; Stephen C Lazarus, MD; Deborah A Meyers, PhD; Wendy C Moore, MD; John D Newell Jr, MD; Robert Paine, III, MD; Laura Paulin, MD, MHS; Stephen P Peters, MD, PhD; Cheryl Pirozzi, MD; Nirupama Putcha, MD, MHS; Elizabeth C Oelsner, MD, MPH; Wanda K O'Neal, PhD; Victor E Ortega, MD, PhD; Sanjeev Raman, MBBS, MD; Stephen I. Rennard, MD; Donald P Tashkin, MD; J Michael Wells, MD; Robert A Wise, MD; and Prescott G Woodruff, MD, MPH. The project officers from the Lung Division of the National Heart, Lung, and Blood Institute were Lisa Postow, PhD, and Lisa Viviano, BSN; SPIROMICS was supported by contracts from the NIH/NHLBI (HHSN268200900013C, HHSN268200900014C, HHSN268200900015C, HHSN268200900016C, HHSN268200900017C, HHSN268200900018C, HHSN268200900019C, HHSN268200900020C), grants from the NIH/NHLBI (U01 HL137880 and U24 HL141762), and supplemented by contributions made through the Foundation for the $\mathrm{NIH}$ and the COPD Foundation from 
AstraZeneca/Medlmmune; Bayer; Bellerophon Therapeutics; Boehringer-Ingelheim Pharmaceuticals, Inc.; Chiesi Farmaceutici S.p.A.; Forest Research Institute, Inc.; GlaxoSmithKline; Grifols Therapeutics, Inc.; Ikaria, Inc.; Novartis Pharmaceuticals Corporation; Nycomed GmbH; ProterixBio; Regeneron Pharmaceuticals, Inc.; Sanofi; Sunovion; Takeda Pharmaceutical Company; and Theravance Biopharma and Mylan.

More information about the study and how to access SPIROMICS data is at www.spiromics.org.

\section{Author Contributions}

VK conceived and designed the analysis plan, performed data analysis and contributed significantly to the writing of the manuscript; SJ generated the data and helped with the data analysis; $\mathrm{HZ}$ performed the data analysis; JK generated the data and helped with the data analysis; JMW, SAC, MD, MKH, RP, CBC, IB, WCM, RB, JLC, RJK, WKO, SIR, and PGW contributed to the data analysis and writing of the manuscript.

\section{References}

1. Collaborators USBoD, Mokdad AH, Ballestros K, Echko M, Glenn S, Olsen HE, Mullany E, Lee A, Khan AR, Ahmadi A, et al: The State of US Health, 1990-2016: Burden of Diseases, Injuries, and Risk Factors Among US States. Jama 2018, 319:1444.

2. Kim V, Criner GJ: The Chronic Bronchitis Phenotype in COPD: Features and Implications. Current opinion in pulmonary medicine 2015, 21:133.

3. Kim V, Zhao H, Boriek AM, Anzueto A, Soler X, Bhatt SP, Rennard SI, Wise R, Comellas A, Ramsdell JW, et al: Persistent and Newly Developed Chronic Bronchitis Are Associated with Worse Outcomes in Chronic Obstructive Pulmonary Disease. Annals of the American Thoracic Society 2016.

4. Allinson JP, Hardy R, Donaldson GC, Shaheen SO, Kuh D, Wedzicha JA: The Presence of Chronic Mucus Hypersecretion across Adult Life in Relation to Chronic Obstructive Pulmonary Disease Development. American journal of respiratory and critical care medicine 2016, 193:662.

5. Hogg JC, Chu F, Utokaparch S, Woods R, Elliott WM, Buzatu L, Cherniack RM, Rogers RM, Sciurba FC, Coxson HO, Pare PD: The nature of small-airway obstruction in chronic obstructive pulmonary disease. The New England journal of medicine 2004, 350:2645.

6. Saetta M, Turato G, Baraldo S, Zanin A, Braccioni F, Mapp CE, Maestrelli P, Cavallesco G, Papi A, Fabbri LM: Goblet cell hyperplasia and epithelial inflammation in peripheral airways of smokers with both symptoms of chronic bronchitis and chronic airflow limitation. American journal of respiratory and critical care medicine 2000, 161:1016.

7. Innes AL, Woodruff PG, Ferrando RE, Donnelly S, Dolganov GM, Lazarus SC, Fahy JV: Epithelial mucin stores are increased in the large airways of smokers with airflow obstruction. Chest 2006, 130:1102.

8. Kim V, Oros M, Durra H, Kelsen S, Aksoy M, Cornwell WD, Rogers TJ, Criner GJ: Chronic Bronchitis and Current Smoking Are Associated with More Goblet Cells in Moderate to Severe COPD and Smokers 
without Airflow Obstruction. PloS one 2015, 10:e0116108.

9. Kim V, Criner GJ, Abdallah HY, Gaughan JP, Furukawa S, Solomides CC: Small airway morphometry and improvement in pulmonary function after lung volume reduction surgery. American journal of respiratory and critical care medicine 2005, 171:40.

10. Hogg JC, Chu FS, Tan WC, Sin DD, Patel SA, Pare PD, Martinez FJ, Rogers RM, Make BJ, Criner GJ, et al: Survival after lung volume reduction in chronic obstructive pulmonary disease: insights from small airway pathology. American journal of respiratory and critical care medicine 2007, 176:454.

11. Sciurba F, Martinez FJ, Rogers RM, Make B, Criner GJ, Cherniak RM, Patel SA, Chu F, Coxson HO, Sharafkhaneh A, et al: The Effect of Small Airway Pathology on Survival Following Lung Volume Reduction Surgery (LVRS). abstract. Proceedings of the American Thoracic Society 2006, 3:A712.

12. Mullen JB, Wright JL, Wiggs BR, Pare PD, Hogg JC: Reassessment of inflammation of airways in chronic bronchitis. British medical journal (Clinical research ed) 1985, 291:1235.

13. Wells JM, Arenberg DA, Barjaktarevic I, Bhatt SP, Bowler RP, Christenson SA, Couper DJ, Dransfield MT, Han MK, Hoffman EA, et al: Safety and Tolerability of Comprehensive Research Bronchoscopy in Chronic Obstructive Pulmonary Disease. Results from the SPIROMICS Bronchoscopy Substudy. Ann Am Thorac Soc 2019, 16:439-446.

14. Image J [http://rsb.info.nih.gov/ij/]

15. Kesimer M, Ford AA, Ceppe A, Radicioni G, Cao R, Davis CW, Doerschuk CM, Alexis NE, Anderson WH, Henderson AG, et al: Airway Mucin Concentration as a Marker of Chronic Bronchitis. The New England journal of medicine 2017, 377:911.

16. Couper D, LaVange LM, Han M, Barr RG, Bleecker E, Hoffman EA, Kanner R, Kleerup E, Martinez FJ, Woodruff PG, et al: Design of the Subpopulations and Intermediate Outcomes in COPD Study (SPIROMICS). Thorax 2014, 69:491.

17. Ferris BG: Epidemiology Standardization Project (American Thoracic Society). The American Review of Respiratory Disease 1978, 118:1.

18. Fligiel SE, Roth MD, Kleerup EC, Barsky SH, Simmons MS, Tashkin DP: Tracheobronchial histopathology in habitual smokers of cocaine, marijuana, and/or tobacco. Chest 1997, 112:319-326.

19. Kesimer M, Smith BM, Ceppe A, Ford AA, Anderson WH, Barr RG, O'Neal WK, Boucher RC, Group SI: Mucin Concentrations and Peripheral Airway Obstruction in Chronic Obstructive Pulmonary Disease. Am J Respir Crit Care Med 2018, 198:1453-1456.

20. Martinez CH, Kim V, Chen Y, Kazerooni EA, Murray S, Criner GJ, Curtis JL, Regan EA, Wan E, Hersh CP, et al: The clinical impact of non-obstructive chronic bronchitis in current and former smokers. Respiratory medicine 2014, 108:491.

21. Burgel PR, Nesme-Meyer P, Chanez P, Caillaud D, Carre P, Perez T, Roche N, Initiatives Bronchopneumopathie Chronique Obstructive Scientific C: Cough and sputum production are associated with frequent exacerbations and hospitalizations in COPD subjects. Chest 2009, 135:975.

22. Kim V, Davey A, Comellas AP, Han MK, Washko G, Martinez CH, Lynch D, Lee JH, Silverman EK, Crapo JD, et al: Clinical and computed tomographic predictors of chronic bronchitis in COPD: a cross 
sectional analysis of the COPDGene study. Respiratory research 2014, 15:52.

23. Kim V, Criner GJ: The chronic bronchitis phenotype in chronic obstructive pulmonary disease: features and implications. Current opinion in pulmonary medicine 2015, 21:133.

24. Vestbo J, Prescott E, Lange P: Association of chronic mucus hypersecretion with FEV1 decline and chronic obstructive pulmonary disease morbidity. Copenhagen City Heart Study Group. American journal of respiratory and critical care medicine 1996, 153:1530.

25. Pelkonen MK, Notkola IK, Laatikainen TK, Jousilahti P: Chronic bronchitis in relation to hospitalization and mortality over three decades. Respiratory medicine 2017, 123:87.

26. Woodruff PG, Barr RG, Bleecker E, Christenson SA, Couper D, Curtis JL, Gouskova NA, Hansel NN, Hoffman EA, Kanner RE, et al: Clinical Significance of Symptoms in Smokers with Preserved Pulmonary Function. The New England journal of medicine 2016, 374:1811.

27. Kim V, Zhao H, Regan E, Han MK, Make BJ, Crapo JD, Jones PW, Curtis JL, Silverman EK, Criner GJ, Investigators CO: The St. George's Respiratory Questionnaire Definition of Chronic Bronchitis May Be a Better Predictor of COPD Exacerbations Compared With the Classic Definition. Chest 2019, 156:685.

28. Guerra S, Sherrill DL, Venker C, Ceccato CM, Halonen M, Martinez FD: Chronic bronchitis before age 50 years predicts incident airflow limitation and mortality risk. Thorax 2009, 64:894-900.

29. Pelkonen M, Notkola IL, Nissinen A, Tukiainen H, Koskela H: Thirty-year cumulative incidence of chronic bronchitis and COPD in relation to 30-year pulmonary function and 40-year mortality: a follow-up in middle-aged rural men. Chest 2006, 130:1129.

30. Forey BA, Thornton AJ, Lee PN: Systematic review with meta-analysis of the epidemiological evidence relating smoking to COPD, chronic bronchitis and emphysema. $B M C$ pulmonary medicine 2011, 11:36.

31. Kim V, Anzueto A, Han MK, Martinez CH, Black-Shinn J, Boriek A, Porszasz J, Soler X, Wise R, Dass C, et al: Persistent and Newly Developed Chronic Bronchitis is Associated with Worse Outcomes and Increased Respiratory Symptoms in Smokers with and without Chronic Obstructive Pulmonary Disease. 2015, 191:A2854.

32. Ebert RV, Terracio MJ: The bronchiolar epithelium in cigarette smokers. Observations with the scanning electron microscope. The American Review of Respiratory Disease 1975, 111:4.

33. Deshmukh HS, Case LM, Wesselkamper SC, Borchers MT, Martin LD, Shertzer HG, Nadel JA, Leikauf GD: Metalloproteinases mediate mucin 5AC expression by epidermal growth factor receptor activation. American journal of respiratory and critical care medicine 2005, 171:305.

34. Holtzman MJ, Tyner JW, Kim EY, Lo MS, Patel AC, Shornick LP, Agapov E, Zhang Y: Acute and chronic airway responses to viral infection: implications for asthma and chronic obstructive pulmonary disease. Proceedings of the American Thoracic Society 2005, 2:132.

35. Burgel PR, Nadel JA: Roles of epidermal growth factor receptor activation in epithelial cell repair and mucin production in airway epithelium. Thorax 2004, 59:992. 
36. Verra F, Escudier E, Lebargy F, Bernaudin JF, De Cremoux H, Bignon J: Ciliary abnormalities in bronchial epithelium of smokers, ex-smokers, and nonsmokers. American journal of respiratory and critical care medicine 1995, 151:630.

37. Button B, Goodell HP, Atieh E, Chen YC, Williams R, Shenoy S, Lackey E, Shenkute NT, Cai LH, Dennis RG, et al: Roles of mucus adhesion and cohesion in cough clearance. Proc Natl Acad Sci U S A 2018, 115:12501-12506.

38. O'Donnell RA, Richter A, Ward J, Angco G, Mehta A, Rousseau K, Swallow DM, Holgate ST, Djukanovic $R$, Davies DE, Wilson SJ: Expression of ErbB receptors and mucins in the airways of long term current smokers. Thorax 2004, 59:1032.

39. Reid LM: Pathology of chronic bronchitis. Lancet 1954, 266:274.

40. Kim V, Chatila WM, Couturie MJ, Lee MQ, Swift AE, Wang P, Shah SA, Abdallah HY, Mylonas E, Kratsios $P$, et al: Small Airway Inflammation and morphometry in Patients with Advanced Emphysema abstract. Proceedings of the American Thoracic Society 2005, 2:A396.

41. Kim WD, Ling SH, Coxson HO, English JC, Yee J, Levy RD, Pare PD, Hogg JC: The association between small airway obstruction and emphysema phenotypes in COPD. Chest 2007, 131:1372.

\section{Figures}
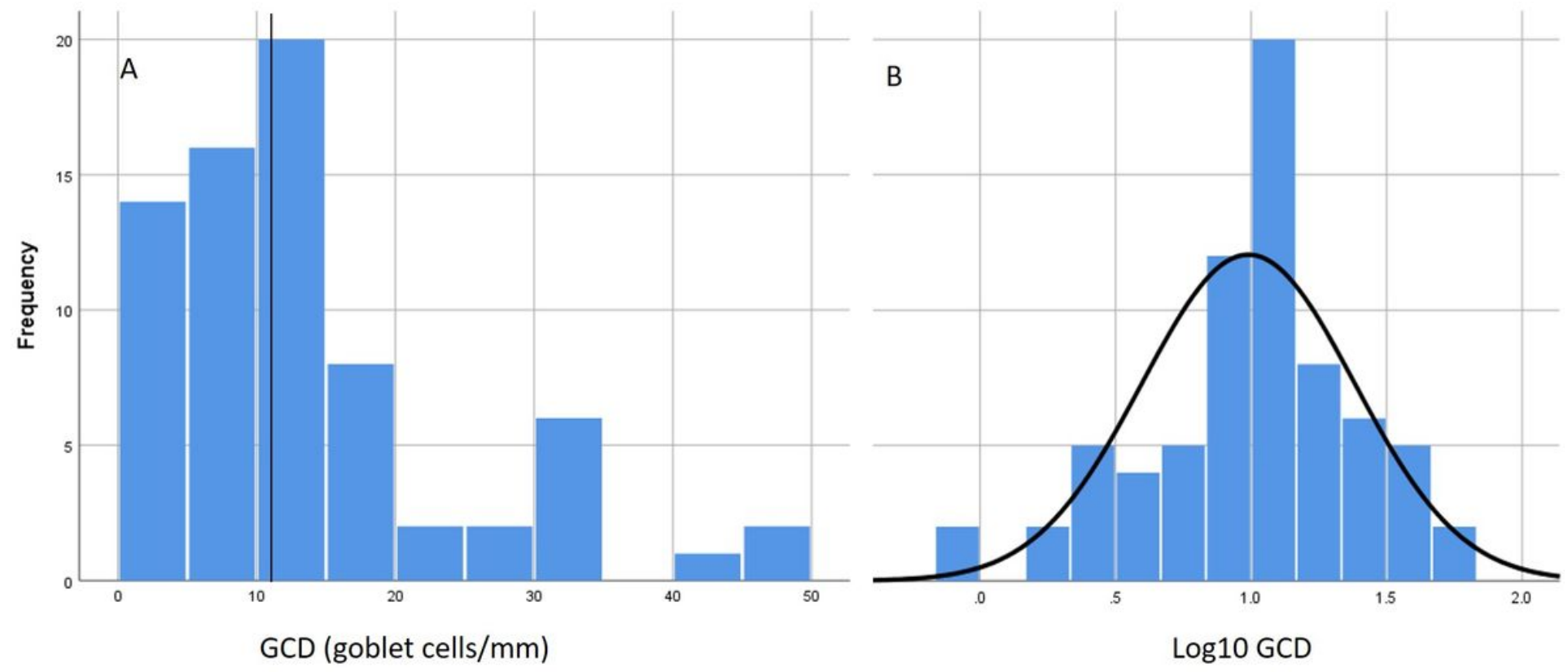

Figure 1

A) Distribution of Goblet Cell Density Measurements. Vertical line represents median value. B) Distribution of log10 Goblet Cell Density Measurements. 


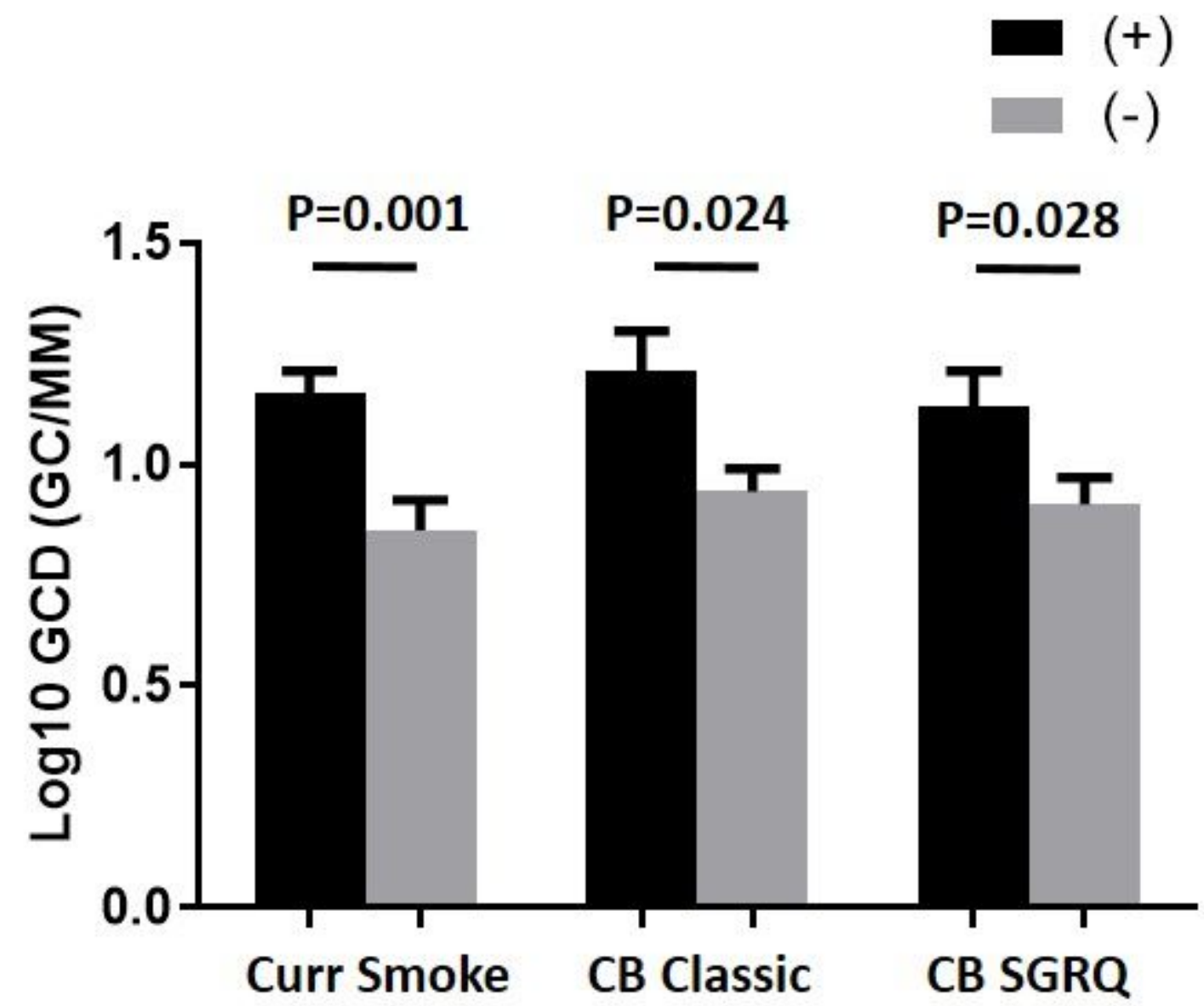

Figure 2

Log10 Goblet Cell Density by Chronic Bronchitis or Smoking Groups. Data expressed as mean \pm SE. GCD

= Goblet Cell Density; CB = Chronic Bronchitis; SGRQ = Saint George's Respiratory Questionnaire. 


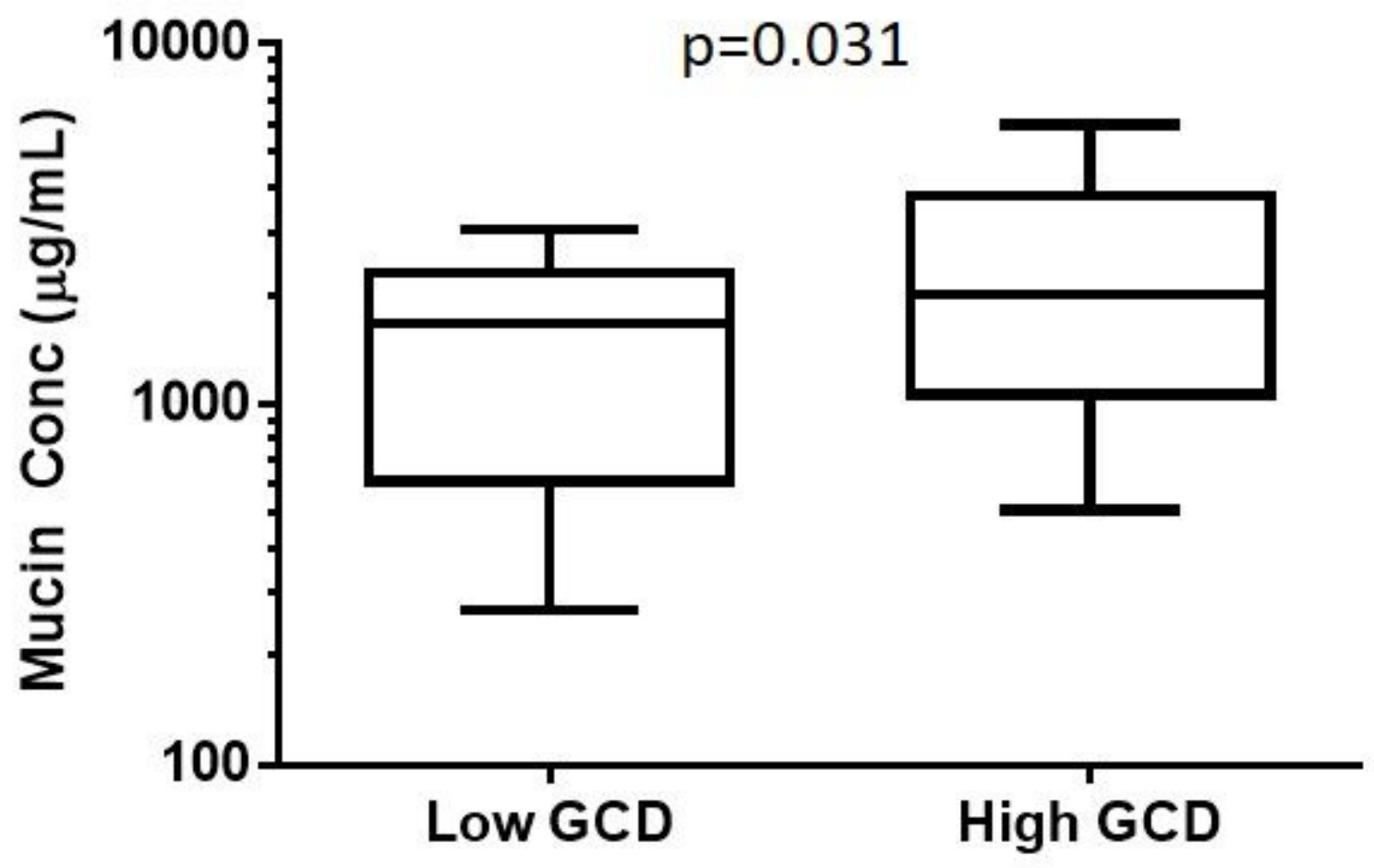

Figure 3

Induced Sputum Mucin Concentrations in Low GCD and High GCD groups.

\section{Supplementary Files}

This is a list of supplementary files associated with this preprint. Click to download.

- CoverLetter.docx 